Int. J. Environ. Res. Public Health 2008, 5(2), 91-98

International Journal of

Environmental Research and Public Health

ISSN 1661-7827

www.ijerph.org

(c) 2008 by MDPI

\title{
Heavy metals in water of the San Pedro River in Chihuahua, Mexico and its potential health risk
}

\author{
Roberto Gutiérrez, L. ${ }^{1}$, Hector Rubio-Arias ${ }^{1 *}$, Ray Quintana ${ }^{1}$, Juan Angel Ortega ${ }^{1}$ and Melida Gutierrez ${ }^{2}$ \\ ${ }^{1}$ College of Zootechnology, Autonomous University of Chihuahua, Mexico, Periferico Francisco R. Almada, Km. 1 carretera \\ Chihuahua-Cuahtemoc, Chihuahua, Chihuahua, Mexico. \\ ${ }^{2}$ Missouri State University, Department of Geography, Geology and Planning, 901 S. National Avenue, Springfield Missouri \\ 65897, USA. \\ *Correspondence to Dr. Hector Rubio-Arias. E-mail: rubioa1105@hotmail.com
}

Received: 29 October 2007 / Accepted: 30 April 2008 / Published: 30 June 2008

\begin{abstract}
The objective of this study was to determine the seasonal and downstream water quality variations of the San Pedro River in Chihuahua, Mexico. Water samples were collected monthly from October 2005 to August 2006 in triplicate, totaling 165 water samples. The five sampling locations were: below the Francisco I. Madero dam (LP); between Rosales and Delicias (RD); Meoqui (M); El Torreon (ET), and Julimes (LJ). The levels of As, Be, Ca, Cd, Co, $\mathrm{Cu}, \mathrm{Cr}, \mathrm{Fe}, \mathrm{Li}, \mathrm{Mg}, \mathrm{Mn}, \mathrm{Mo}, \mathrm{Ni}, \mathrm{Pb}, \mathrm{Sb}, \mathrm{Se}, \mathrm{Sr}, \mathrm{Ti}, \mathrm{Ta}, \mathrm{V}$ and $\mathrm{Zn}$ were measured using an Inductively Coupled PlasmaOptical Emission Spectrometry (ICP-OES) Perkin Elmer 2100. In addition, temperature, pH, electrical conductivity and total and fecal coliformes were determined. The statistical analysis considered a factorial treatment design; where factor A was the location point and factor B was sampling date. In addition, a multivariate technique looking for principal components was performed. The results indicated that some samples exceeded Mexican standards for As, Be, $\mathrm{Ca}, \mathrm{Cd}, \mathrm{Co}, \mathrm{Cr}, \mathrm{Fe}, \mathrm{Mn}, \mathrm{Ni}, \mathrm{Pb}, \mathrm{Sb}, \mathrm{Se}, \mathrm{Sr}$ and $\mathrm{Zn}$. The As level must be considered for a red flag to the communities along the Rio San Pedro because both the monthly average level $\left(0.10 \mathrm{mg} \mathrm{L}^{-1}\right)$ and location $\left(0.10 \mathrm{mg} \mathrm{L}^{-1}\right)$ exceeded the Mexican and International norms. The multivariate analysis showed a predominant aggregation at the LP location, meaning that there was a predominance of As, Sr, Fe and Li. At the rest of the locations the elements did not present a tendency for aggregation. Statistics applied to sampling month showed that December, January, March and April were aggregated in a negative quadrant of component 1 indicating a predominance of $\mathrm{V}, \mathrm{Ni}, \mathrm{Be}, \mathrm{Fe}$ and As. Overall, the results confirmed that this stretch of the San Pedro River is contaminated with heavy metals and other contaminants that might affect human health as well as the health of the ecosystem.
\end{abstract}

Keywords: Chihuahua, metals, metalloids, Mexico, water quality

\section{Introduction}

The concern for water resources containing contaminants, such as heavy metals and toxic metalloids, that pose a threat to health, has increased worldwide. The presence of metals in water results from two independent factors. The first involving the weathering of soils and rocks [1-3] with its products being transported by air $[4,5]$ and water [6], and the second involving a variety of anthropogenic activities that have created a societal health risk in rivers that receive a substantial amount of waste, as it is the case of the Rio San Pedro. In diverse aquatic environments within the state of Chihuahua, Mexico, the evidence of contamination points to anthropogenic activities [7-9]. For instance, the Conchos River is considered essential for more than a million inhabitants [10] and receives wastewater discharges from urban drainage as well as waste products from agriculture and industrial activities [7]. In addition, the Conchos watershed ails from other kind of anthropogenic-related impacts such as water-level fluctuations caused by dams and channelizing.

To date, the Conchos River has been reported to be contaminated, to some degree, with metals and metalloids [10-12]. In a study conducted in six tributaries of the Conchos River Rubio et al., [8] detected levels of As up to $0.0192 \mathrm{mg} \mathrm{l}^{-1}$ in the Chuviscar River and $0.2413 \mathrm{mg} \mathrm{l}^{-1}$ in 
the Conchos River before its junction with the Río Grande/Río Bravo. In another study by Holguin et al., [11] for the Conchos River near Ojinaga, the element $\mathrm{Al}$ amounted to four times the standard established by the Mexican's official norms; Mn, Ti and Fe three times the standard while $\mathrm{Ba}, \mathrm{Be}, \mathrm{Na}, \mathrm{Ni}$ and $\mathrm{Zn}$ were found at concentrations up to two times the limit value.

Even though there is information about the level of contamination in the Conchos River and its tributaries; no information is available concerning this problem in the San Pedro River. This information is important when it is considered that inhabitants of Meoqui as well as other communities of the center part of the state of Chihuahua have direct contact with this resource. The hypothesis of this study was that the Rio San Pedro has not escaped the effects of pollution, and that in synergy with the recurrent droughts that affect the state, its polluted condition has severely increased the problem. In order to quantify the severity of the pollution, metal and metalloid concentrations as well as other quality parameters such as coliforms were determined. The results obtained here will be beneficial for preventive as well as correctional schemes to the inhabitants of the area and in the design of a basin management program towards recovery of this river's ecosystem. Furthermore, these results will be important and necessary to be included in ongoing health-related programs in the central part of the state of Chihuahua.

\section{Materials and Methods}

Water flow of the Conchos River originates in the mountain area of the state of Chihuahua, Mexico about 2,700 meters above sea level (masl). Stream down flows to the great plains about 1,000-1,500 masl, and then, the water of Conchos River joins the Rio Bravo/Rio Grande water at 720 masl in Ojinaga, Chihuahua in the Mexican side and in the community of Presidio, Texas in the American side. The Rio Bravo/Rio Grande serves as a natural boundary between Mexico and the United States of America. This study was carried out in the Rio San Pedro, a tributary of the Rio Conchos; and hence, part of the Rio Bravo basin. The stretch of the San Pedro River studied here started below the Las Virgenes dam (348 million $\mathrm{m}^{3}$ capacity) to the confluence of the Rio San Pedro with the Rio Conchos (before the water is stored again in the Granero dam; 356 million capacity). The study area is located within the Irrigation District 005, which is considered one of the most important in Mexico, and includes the municipalities of Rosales, Delicias, Julimes and Meoqui.

Five sites along that part of the San Pedro River were selected for sample collection. Water samples were collected monthly by triplicate, from October 2005 to August 2006. Therefore, a total of 165 water samples were collected. Point 1 was located downstream Las Virgenes dam (North Latitude $28^{\circ} 09^{`} 898^{`}$; West Longitude $105^{\circ}$ $37^{`} 541$; 1,206 masl). This point will be referred to as $\mathrm{La}$ Presa (LP). Point 2 was located between the community of Rosales and the city of Delicias (North Latitude $28^{\circ} 15^{\circ}$ 406`; West Longitude $105^{\circ} 29^{`} 409 `$; 1,150 masl). This point will be referred as Rosales-Delicias (RD). Sampling point 3 was close to the city of Meoqui (North Latitude $28^{\circ}$ $16 ` 343^{`}$; West Longitude $105^{\circ} 27^{`} 699^{`}$; 1,132 masl). This point will be referred as Meoqui (M). Point 4 was located in the community of El Torreon (North Latitude $28^{\circ} 19^{\circ}$ $335^{`}$; West Longitude $105^{\circ} 25^{`} 140 ` 1,129$ masl). This point will be referred to as El Torreon (ET). Point 5 was located in the community El Gramal (North Latitude $28^{\circ}$ 20`998`; West Longitude $105^{\circ} 24^{`} 882 `$; 1,117 masl). This point will be referred as La Junta (LJ).

The temperature was determined in situ according with the Mexican Norm NMX-AA-007-SCF [13] using a mercury thermometer with a range of $-10^{\circ} \mathrm{C}$ to $100^{\circ} \mathrm{C}$. The electrical conductivity (EC) was determined in situ following the Mexican Norm NMX-AA-093-SCF [14] using a conductivity meter Hanna with a range of 0.01$19.99 \mathrm{dSm}^{-1}$. The $\mathrm{pH}$ was determined according with the Mexican Norm NMX-AA-008-SCFI [15] using a standard glass electrode $\mathrm{pH}$ device Oaktron Model 35624-50 with a range of -1.0 to $15-0$.

Water samples were collected in sterilized containers, preserved in a cool place (about $4^{\circ} \mathrm{C}$ ) and transported to the laboratory of the College of Zootechnology of the Autonomous University of Chihuahua (UACH) for further analysis. In the particular case of water samples, to evaluate total and fecal coliformes, the samples were transported to the College of Chemistry of the UACH. The water samples were analyzed according to APHA procedures [16] as well as the Mexican Official Norms [17].

The evaluated metals were Arsenic (As), Beryllium (Be), Calcium (Ca), Cadmium (Cd), Cobalt (Co), Cupper $(\mathrm{Cu})$, Chromium ( $\mathrm{Cr})$, Iron (Fe), Lithium (Li), Magnesium (Mg), Manganese (Mn), Molybdenum (Mo), Nickel (Ni), Lead (Pb), Antimony (Sb), Selenium (Se), Strontium (Sr), Titanium (Ti), Tantalum (Ta), Vanadium (Va) and Zinc (Zn). The determination of metals was done using an Inductively Coupled Plasma-Optical Emission Spectrometer (ICP-OES) Perkin Elmer 2100, after a metal extraction according to Mexican Norm NMX-AA-051SCFI [18] which was conducted, as follows. A portion of the water sample $(100 \mathrm{ml})$ was filtered using a Whatman paper and digested with $5 \mathrm{ml}$ of concentrated $\mathrm{HNO}_{3}$, until complete digestion was obtained. For the different element's determination, standards of known concentration were prepared for each element, followed by calibration of the wave longitude, plasma position, gas flux and sensibility for each element.

The statistical analysis for each element included a factorial treatment design; where factor A was the location point and factor B was sampling date. The differences were noted using a 0.05 significance level for main effects as well as for the interaction effect. Finally, a Multiple Analysis of Variance (MANOVA) was performed using 15 elements from which principal components were identified.

\section{Results and Discussion}

The average temperature was $24^{\circ} \mathrm{C} \pm 3.85$. This parameter varied with sampling location, time of collection 
and season of the year. These results are similar to those reported by Rubio et al., [8] and Holguin et al., [11]. The $\mathrm{pH}$ values detected in water of the San Pedro River were found to be in the permissible range of 6.5 to 8.5 [19]. The average was $7.69 \pm(0.405)$ indicating a slightly alkaline water. These results agree with those reported by Gutierrez and Borrego [10] and Rubio et al., [8] who quantified $\mathrm{pH}$ values in other tributaries of the Conchos River. With respect to EC, it can be noted that values increased downstream, from only $0.29 \mathrm{dSm}^{-1}$ at the LP site to 1.62 $\mathrm{dSm}^{-1}$ at the LJ site. The average EC was $1.33 \mathrm{dSm}^{-1}$. These results are similar to those presented by Holguin et al., [11] who evaluated EC in the Conchos River near Ojinaga, Chihuahua.

The results for As in this study showed variability for both sampling location and sampling month. In Figure 1, it is evident that the location LP in the upper part of the river was less contaminated with $0.07 \mathrm{mg} \mathrm{L}^{-1}$ in comparison with the other points; the maximum amount was detected in $\mathrm{LJ}$ with $0.16 \mathrm{mg} \mathrm{L}^{-1}$.

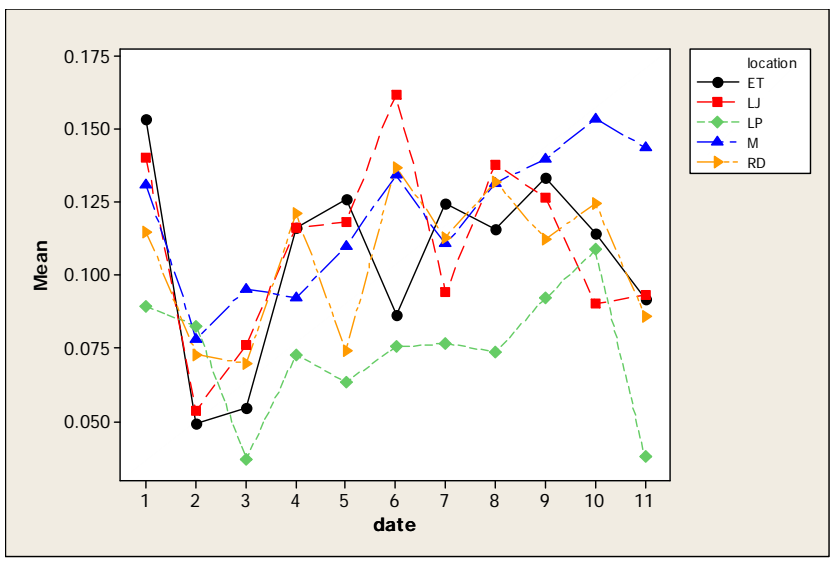

Figure 1: Concentration of As in water considering five location points and 11 consecutive months of sampling (date 1 corresponds to October 2005)

Furthermore, most As concentrations are higher than the values recommended in Mexican and International norms for drinking water. It is important to point out that As level was found above the Mexican Norm in most of the samples. Even though the inhabitants settled in rural communities close to the river do not drink this water, they come in direct contact with this by means of other activities such as bathing and crop irrigation. In Addition, some concentrations were also higher than that established in Mexican norms for water used in agriculture $(0.10 \mathrm{mg} \mathrm{L}$ $\left.{ }^{1}\right)$. The findings reported here, must be an alert to health agencies in Chihuahua`s communities because this element has been associated to development of Leukemia [20], abnormalities in children [21] cancer [22, 23] and with various other diseases [24, 25]. Another concern is that people living in the communities along the San Pedro River as well as many people for the urban areas of Chihuahua consume fish or other products collected from the river, and at the present time there is no information about the level of contamination in edible tissues of these products.

The Analysis of Variance showed significant differences for Be concentration due to sampling point, sampling month as well as the interaction (Figure 2). Be is not considered an essential element for human and, in fact, is toxic and responsible for the chronic beryllium disease [26] caused by beryllium exposure. In this study, the average Be concentration in some locations and sampling months was higher than the limits for drinking water (0.00007 $\mathrm{mg} \mathrm{L}^{-1}$ ) established in the Mexican Norm CECCA-001/89. The lowest Be concentration was reported in $\mathrm{LP}$ with $0.011 \mathrm{mg} \mathrm{L}^{-1}$ while the highest was noted in $\mathrm{LJ}$ with $0.014 \mathrm{mg} \mathrm{L}^{-1}$. The mean of Be was higher in June and July with $0.035 \mathrm{mg} \mathrm{L}^{-1}$ while the lowest average value was in November with $0.002 \mathrm{mg} \mathrm{L}^{-1}$ and December with 0.0006 $\mathrm{mg} \mathrm{L}^{-1}$.

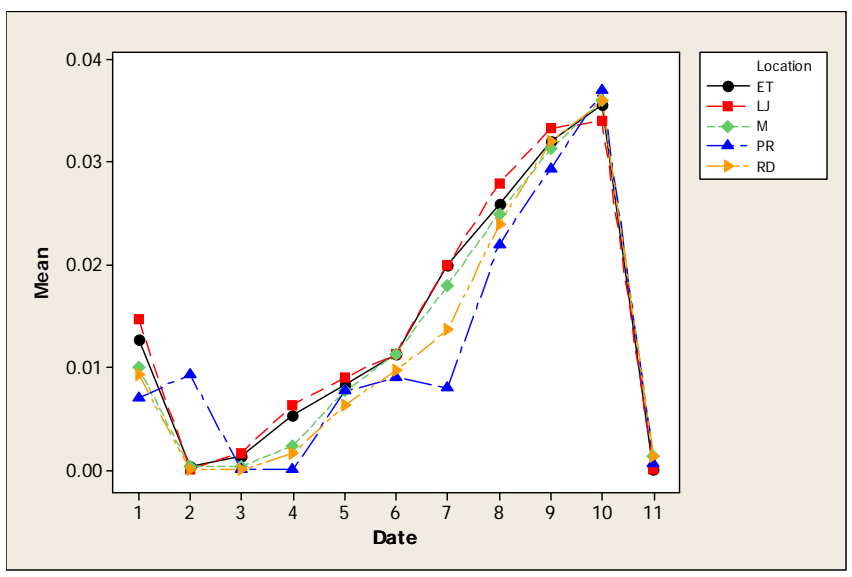

Figure 2: Interaction plot for Be in water considering five location points and 11 consecutive months of sampling (month 1 corresponds to October 2005)

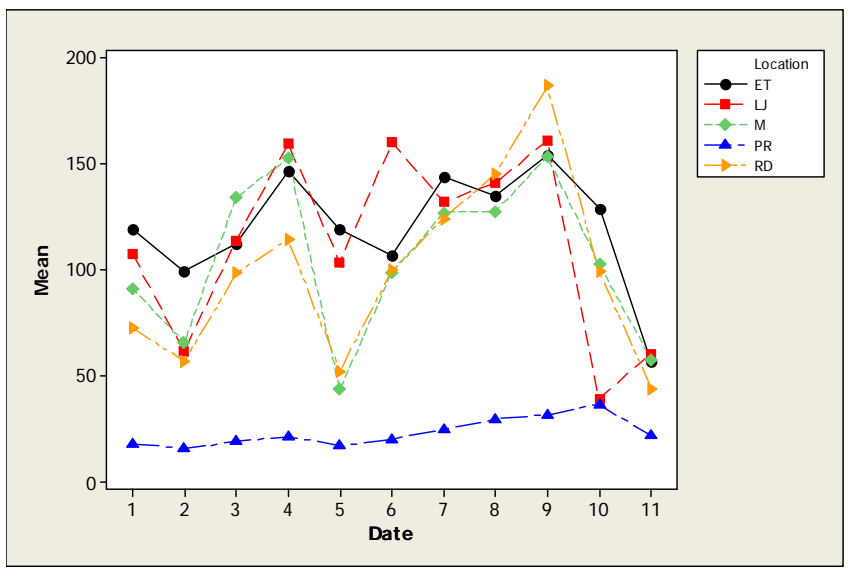

Figure 3: Interaction plot for $\mathrm{Ca}$ in water considering five location points and 11 consecutive months of sampling (month 1 corresponds to October 2005).

With respect to the element $\mathrm{Ca}$, there were statistical differences in concentration due to sampling location, sampling month as well as for the interaction (Figure 3). 
The lower Ca concentration was observed in the upper part of the river (LP) with a mean of $23.21 \mathrm{mg} \mathrm{L}^{-1}$ and as the water flows down, the Ca concentration increased to reach an average of $120.23 \mathrm{mg} \mathrm{L}^{-1}$ in ET. With respect to sampling date, it was noted that maximum amount of $\mathrm{Ca}$ was observed in rainy months, which also correspond to the period of time when fields are being irrigated, reaching a high in June with $137.50 \mathrm{mg} \mathrm{L}^{-1}$ compared to the 59.74 $\mathrm{mg} \mathrm{L}^{-1}$ obtained in November. These results are lower than those reported by Holguin et al., [11] who found an average of Ca concentration of $205 \mathrm{mg} \mathrm{L}^{-1}$ in water of the Conchos River near Ojinaga.

The Cd concentration was different just for sampling month and no statistical differences were noted for sampling location neither for the interaction. The maximum level of $\mathrm{Cd}$ was observed in March with an average of $0.014 \mathrm{mg} \mathrm{L}^{-1}$ while the concentration for the rest of the months was quite homogeneous. The Analysis of Variance detected statistical differences in Co concentration for sampling month as well as for the interaction; nevertheless, not differences were noted for sampling locations. Figure 4 shows the interaction plot for this element, showing an average mean concentration in a range of 0.002 to $0.003 \mathrm{ppm}$ in all locations. Maximum Co levels were obtained in November and December with values of $0.007 \mathrm{mg} \mathrm{L}^{-1}$ and $0.008 \mathrm{mg} \mathrm{L}^{-1}$, respectively. The levels of Co found in this study are similar to the results reported by Holguin et al., [11]. The $\mathrm{Cu}$ concentration was statistical different just for sampling months. The maximum level of Cu was obtained in July with $0.20 \mathrm{mg} \mathrm{L}$ 1. In fact, higher concentration of this element was observed during the irrigation-rainy season ` months while the lower concentration persisted for the rest of the months.

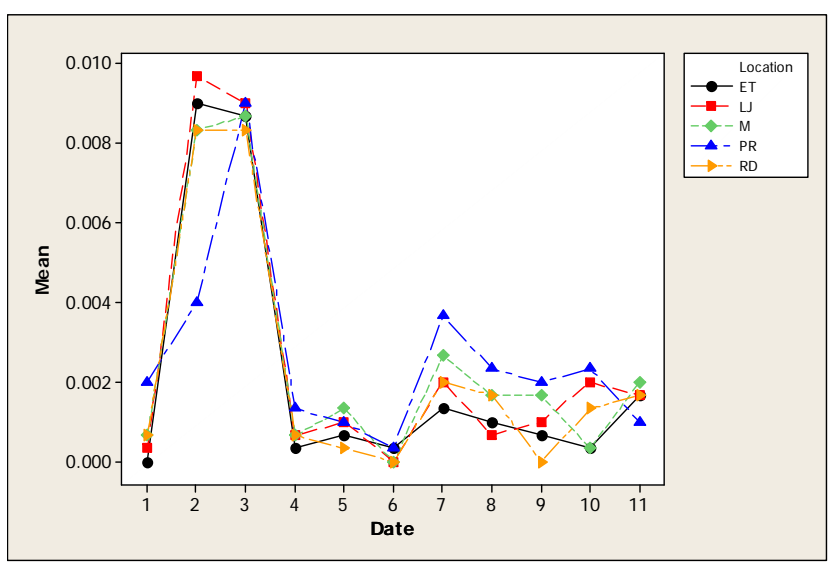

Figure 4: Interaction plot for Co in water considering five location points and 11 consecutive months of sampling (month 1 corresponds to October 2005)

The element Cr was different for sampling location, sampling month and the interaction (Figure 5). The lowest $\mathrm{Cr}$ concentration was obtained in location LP with $0.06 \mathrm{mg}$ $\mathrm{L}^{-1}$, followed for a level of $0.07 \mathrm{mg} \mathrm{L}^{-1}$ in $\mathrm{RD}, \mathrm{M}$ and $\mathrm{ET}$, while the high level was noted in LJ with $0.08 \mathrm{mg} \mathrm{L}^{-1}$. It is important to point out that the concentration of $\mathrm{Cr}$ in water of the San Pedro River in some months and in all locations exceeded the standards established in Mexican norm CECCA-001 for drinking water $\left(0.05 \mathrm{mg} \mathrm{L}^{-1}\right)$. For instance, Cr concentration in June was $0.160 \mathrm{mg} \mathrm{L}^{-1}$, in July 0.192 $\mathrm{mg} \mathrm{L}^{-1}$ and in August $0.212 \mathrm{mg} \mathrm{L}^{-1}$. These results are higher than those reported by Rubio et al., [8] in water of the Conchos River. It will be important to share this information with the health system in Chihuahua, Mexico, because this is a toxic metal, able to cause a variety of diseases [27, 28].

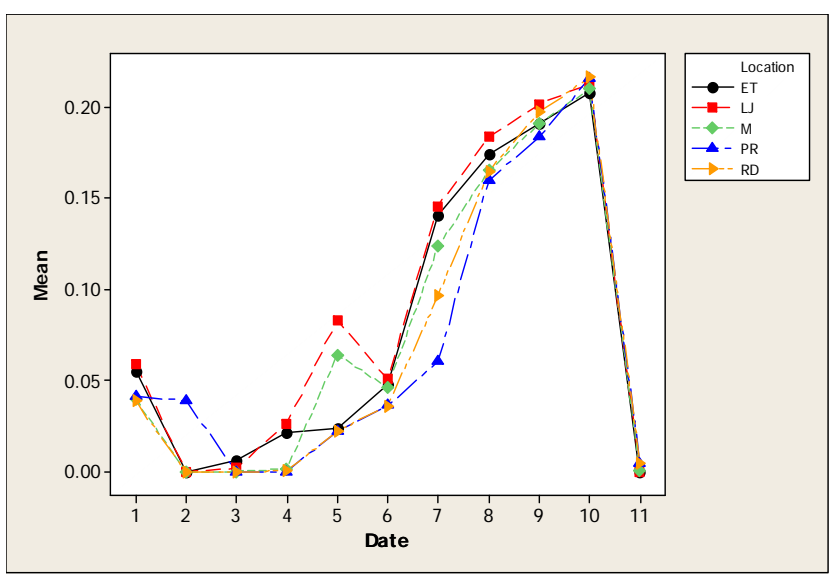

Figure 5: Interaction plot for $\mathrm{Cr}$ in water considering five location points and 11 consecutive months of sampling (month 1 corresponds to October 2005)

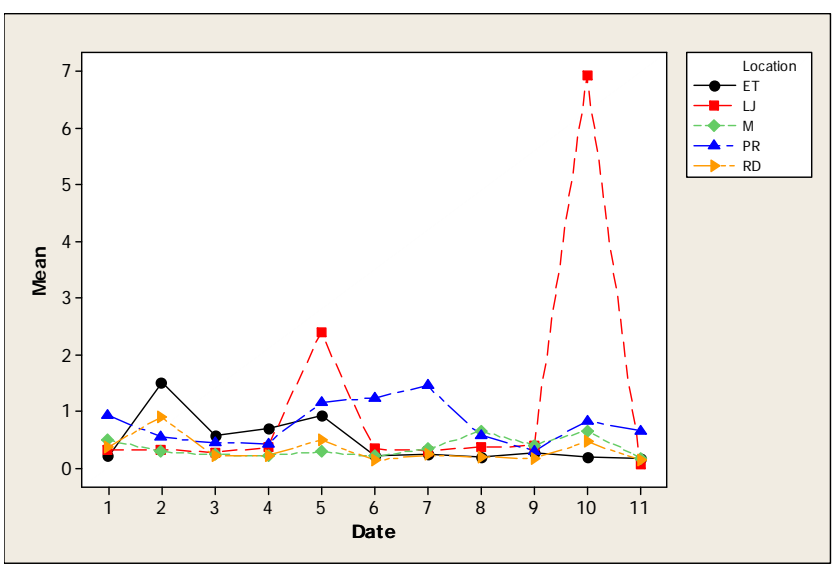

Figure 6: Interaction plot for $\mathrm{Fe}$ in water considering five location points and 11 consecutive months of sampling (month 1 corresponds to October 2005)

The Fe concentration was different with respect to sampling location, sampling month and the interaction (Figure 6). The maximum amount of Fe was found in $\mathrm{LJ}$ with $1.09 \mathrm{mg} \mathrm{L}^{-1}$. With respect to sampling month, the high concentration was detected in July with $1.80 \mathrm{mg} \mathrm{L}^{-1}$. These values exceeded the limited value established in the Mexican Norm $\left(0.3 \mathrm{mg} \mathrm{L}^{-1}\right)$. High levels of Iron represent an irony due to the fact that in the upper reaches of the Conchos and San Pedro, known as the Tarahumara region, live more than 80,000 Tarahumara Indians with iron 
deficiency symptoms [29]. The Fe-content results agree with those reported by Holguin et al., [11] and Rubio et al., [8].

Li differences were observed as a function of sampling location, sampling month and the interaction (Figure 7). It can be seen from this figure that the minimum $\mathrm{Li}$ concentration with $0.02 \mathrm{mg} \mathrm{L}^{-1}$ was detected in LP while in the location $\mathrm{LJ}$ the concentration was as high as $0.31 \mathrm{mg} \mathrm{L}^{-1}$. According to the significant difference in Li concentration between the upper location and the lowest location, it can be hypothesized that this difference was caused by anthropogenic effects, possibly an effect of irrigation. Considering sampling months, the maximum levels were detected in March with $0.331 \mathrm{mg} \mathrm{L}^{-1}$ and June with 0.307 $\mathrm{mg} \mathrm{L}^{-1}$. The Li amounts observed in this study are higher than results of other studies in different environments [30, 31]. The most important aspect to point out is the potential toxic effects of this element in some organisms that live in water of the San Pedro River, when is analyzed that levels of $0.4 \mathrm{mg} \mathrm{L}^{-1}$ could be toxic to some insect larvae [32].

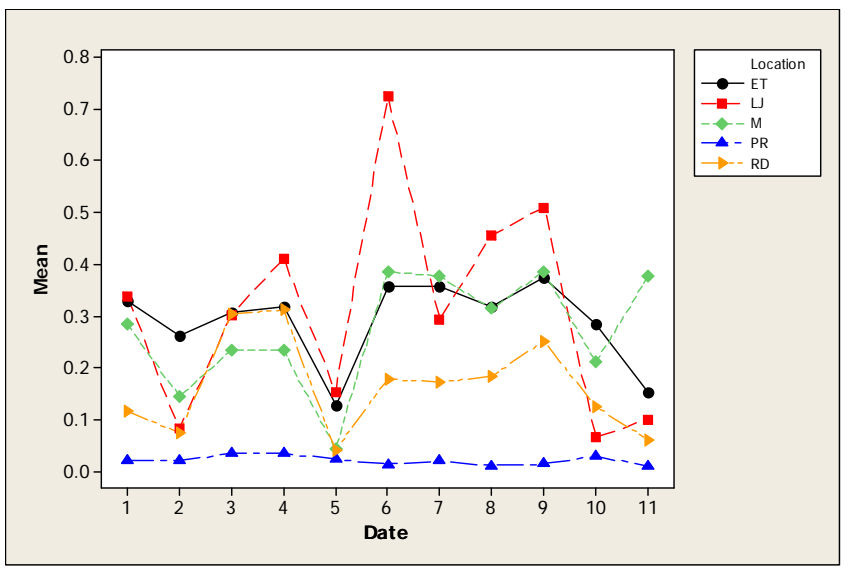

Figure 7: Interaction plot for $\mathrm{Li}$ in water considering five location points and 11 consecutive months of sampling (month 1 corresponds to October 2005)

The Mg levels were different for sampling location, sampling month and the interaction as based on the analysis of variance. It is evident from Figure 8 that the lowest $\mathrm{Mg}$ concentration occurred in LP with $5.82 \mathrm{mg} \mathrm{L}^{-1}$ in comparison with the rest of the sampling locations whose values were $21.59 \mathrm{mg} \mathrm{L}^{-1}$ in $\mathrm{RD}, 27.43 \mathrm{mg} \mathrm{L}^{-1}$ in $\mathrm{M}$, $28.59 \mathrm{mg} \mathrm{L}^{-1}$ in ET and $26.84 \mathrm{mg} \mathrm{L}^{-1}$ in LJ. Considering the sampling month, the maximum levels of $\mathrm{Mg}$ were detected in June with $33.08 \mathrm{mg} \mathrm{L}^{-1}$. There were no differences for Mn concentration for the factor of sampling location neither the interaction; but significant differences were noted for sampling month (Figure 9). The maximum levels were noted during winter time with $4.36 \mathrm{mg} \mathrm{L}^{-1}$ in December and $4.62 \mathrm{mg} \mathrm{L}^{-1}$ in January. The Mo concentration was different for sampling location, sampling month and the interaction (Figure 10). It can be noted that in LP was the lowest Mo concentration with $0.006 \mathrm{mg} \mathrm{L}-1$ and in the rest of the locations the amount of Mo was similar. Differences for sampling month and the interaction were noted for $\mathrm{Ni}$; nevertheless, no differences were observed for sampling location. Figure 11 shows that the lowest amount of $\mathrm{Ni}$ was detected in LP with $0.16 \mathrm{mg} \mathrm{L}^{-1}$ followed by 0.21 $\mathrm{mg} \mathrm{L}^{-1}$ in $\mathrm{M}$. During June the highest Ni concentration was $0.30 \mathrm{mg} \mathrm{L}^{-1}$ followed by July with $0.23 \mathrm{mg} \mathrm{L}^{-1}$.

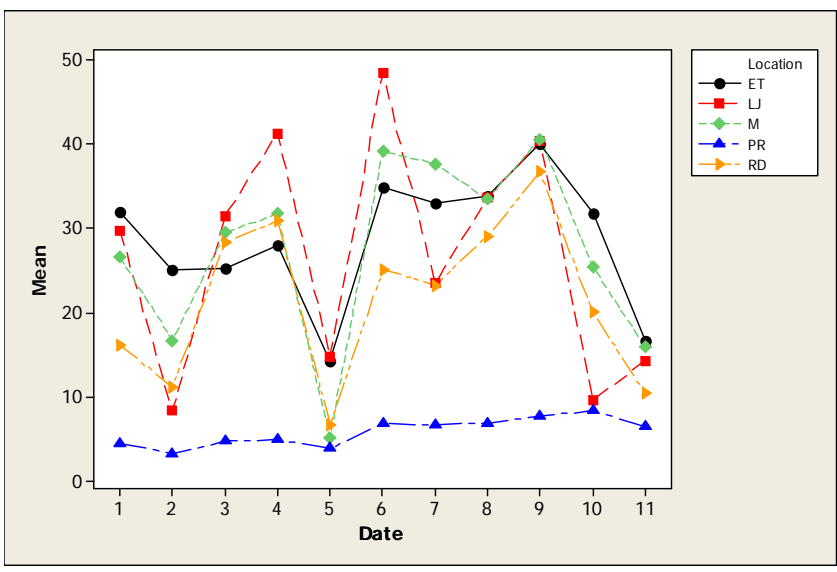

Figure 8: Interaction plot for $\mathrm{Mg}$ in water considering five location points and 11 consecutive months of sampling (month 1 corresponds to October 2005)

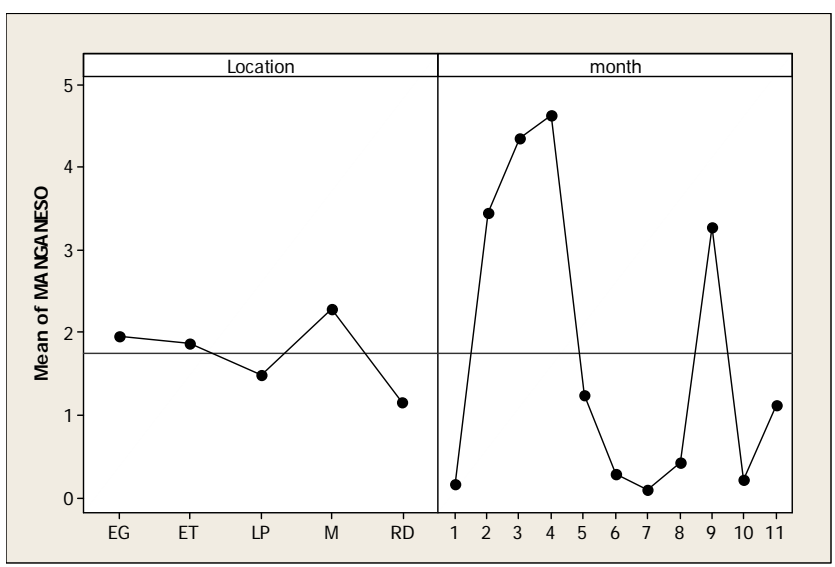

Figure 9: Main factors for $\mathrm{Mn}$ in water considering five sampling location and 11 consecutive sampling months (month 1 corresponds to October 2005)

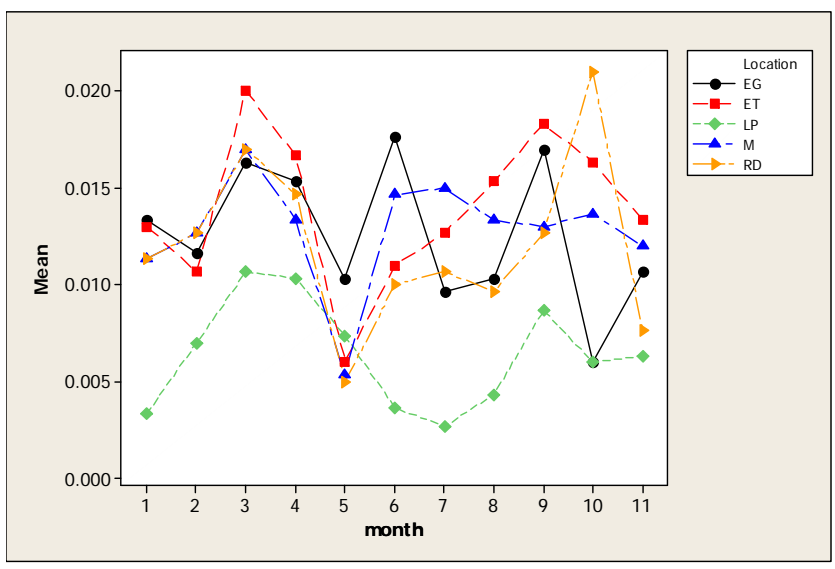

Figure 10: Interaction plot for $\mathrm{Mo}$ in five sampling locations and 11 consecutive months of sampling (month 1 corresponds to October 2005) 


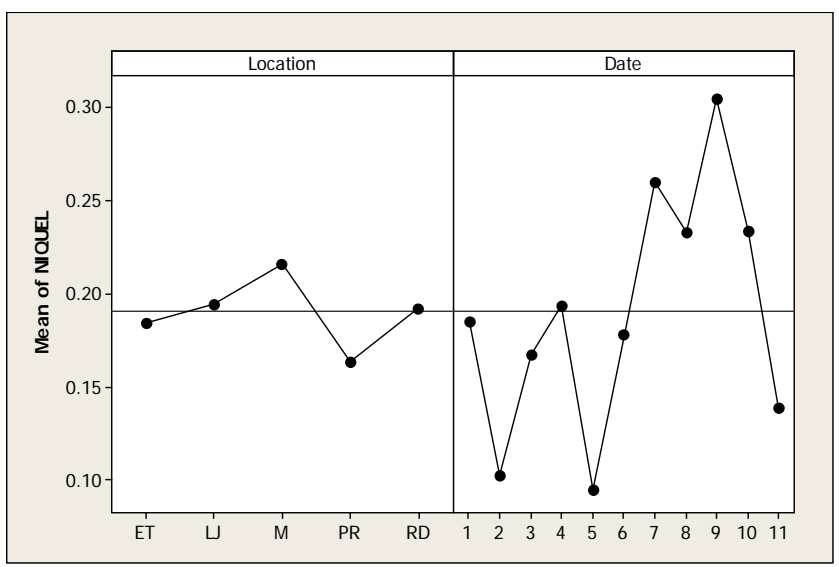

Figure 11: Main factors effects for $\mathrm{Ni}$ in five locations and 11 consecutive month sampling (month 1 corresponds to October 2005)

Significant differences were noted for the element $\mathrm{Sr}$, considering both factors as well as the interaction (Figure 12). It was evident that the minimum amount of Sr was detected in LP with $0.33 \mathrm{mg} \mathrm{L}^{-1}$ and in the way that the water flows down the river, the amount of this element increased to $2.25 \mathrm{mg} \mathrm{L}^{-1}$ in ET and $2.18 \mathrm{mg} \mathrm{L}^{-1}$ in LJ. Maximum levels in sampling months were found for May with $2.07 \mathrm{mg} \mathrm{L}^{-1}$ and June with $2.44 \mathrm{mg} \mathrm{L}^{-1}$. It can be said that none of the averages of $\mathrm{Sr}$ exceeded the Mexican Norm 127-SSAI for drinking water limit established at 4.0 $\mathrm{mg} \mathrm{L}^{-1}$.

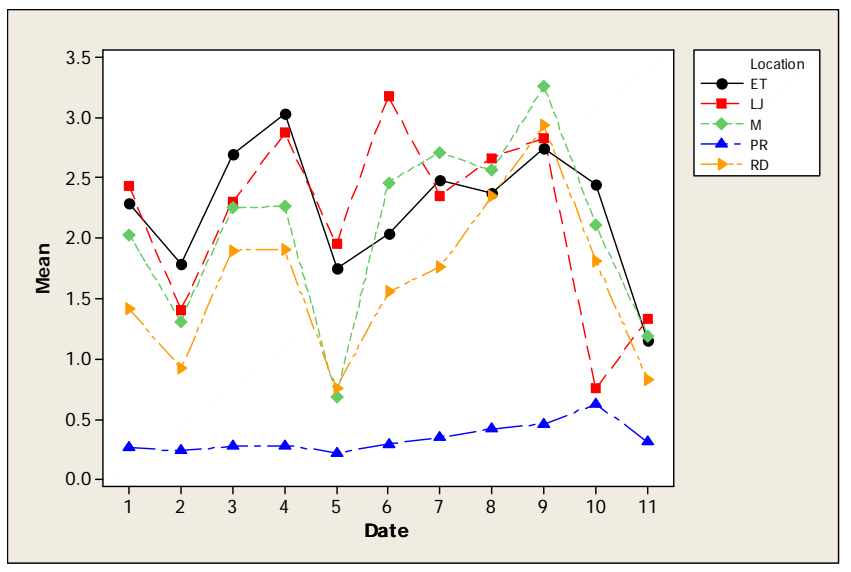

Figure 12: Interaction plot for $\mathrm{Sr}$ in water considering five location points and 11 consecutive months of sampling (month 1 corresponds to October 2005)

Figure 13 shows the interaction plot of the element $\mathrm{V}$ for the factors of sampling locations and sampling months. The lowest concentration was observed in LP with 0.015 $\mathrm{mg} \mathrm{L}^{-1}$ and it can also be seen that the lowest concentration occurs in winter time and the higher level during the rainy season with $0.06 \mathrm{mg} \mathrm{L}^{-1}$ in August. These results differ from those reported by Rubio et al., [33] obtained for different tributaries of the Conchos River. The elements $\mathrm{Pb}, \mathrm{Sb}, \mathrm{Se}, \mathrm{Ti}, \mathrm{Ta}, \mathrm{Zn}$ were not affected by sampling month and sampling locations and no regular trend was noted for these elements.

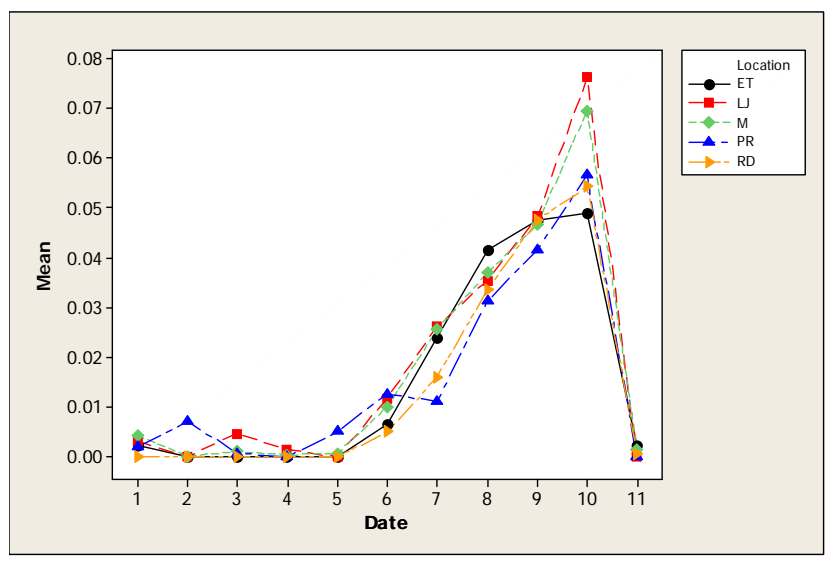

Figure 13: Interaction plot for $\mathrm{V}$ in water considering five location points and 11 consecutive months of sampling (month 1 corresponds to October 2005)

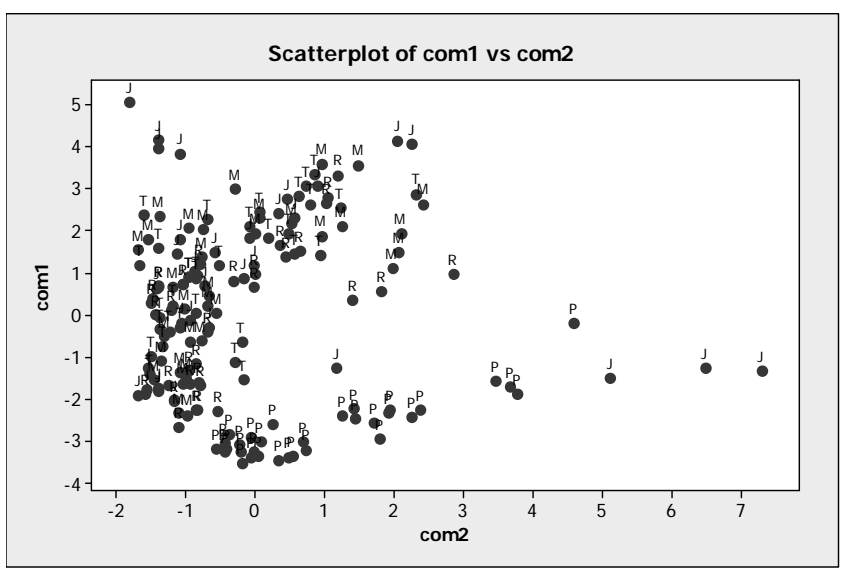

Figure 14: Análisis of the component 1 and component 2 associated to sampling points in the San Pedro River, where $\mathrm{P}=$ point $\mathrm{LP}$; $\mathrm{R}=$ point $\mathrm{RD} ; \mathrm{M}=$ point $\mathrm{M} ; \mathrm{T}=$ point ET; J=point LJ

The results of the multivariate analysis associated to locations (Figure 14) showed positive values in the component 1 for $\mathrm{Mg}\left(0.447 \mathrm{mg} \mathrm{L}^{-1}\right)$, Sr $\left(0.444 \mathrm{mg} \mathrm{L}^{-1}\right)$, Ca (0.432 $\left.\mathrm{mg} \mathrm{L}^{-1}\right)$ and $\mathrm{Li}\left(0.417 \mathrm{mg} \mathrm{L}^{-1}\right)$ as well as negative values for As (0.162 $\left.\mathrm{mg} \mathrm{L}^{-1}\right)$ and Fe $\left(0.102 \mathrm{mg} \mathrm{L}^{-1}\right)$. With respect to component 2, there were positive values for $\mathrm{V}$ (0.537 $\left.\mathrm{mg} \mathrm{L}^{-1}\right)$, Be $\left(0.488 \mathrm{mg} \mathrm{L}^{-1}\right)$, Fe $\left(0.377 \mathrm{mg} \mathrm{L}^{-1}\right)$ and $\mathrm{Ni}\left(0.313 \mathrm{mg} \mathrm{L}^{-1}\right)$ as well as negative values for $\mathrm{Li}(0.135$ $\left.\mathrm{mg} \mathrm{L}^{-1}\right)$ and $\mathrm{Sr}\left(0.101 \mathrm{mg} \mathrm{L}^{-1}\right)$. It was evident a predominant aggregation of LP location in the positive quadrant of component 2 and negative of component 1 , meaning that, in this particular location, there was mainly the presence of As, Sr, Fe and Li. The rest of the locations did not present a tendency of aggregation. The analysis of the component 1 and component 2 associated to sampling months showed that December, January, March and April had a tendency for aggregation in the negative quadrant of 
the component 1 , meaning that in those months, there was presence of $\mathrm{Va}, \mathrm{Ni}, \mathrm{Be}, \mathrm{Fe} y$ As (Figure 15). This results were verified using a multivariance analysis (MANOVA) in order to obtain statistical differences for sampling month effect $(\mathrm{P}<0.05)$, location $(\mathrm{P}<0.05)$ and for the interaction $(\mathrm{P}<0.05)$.

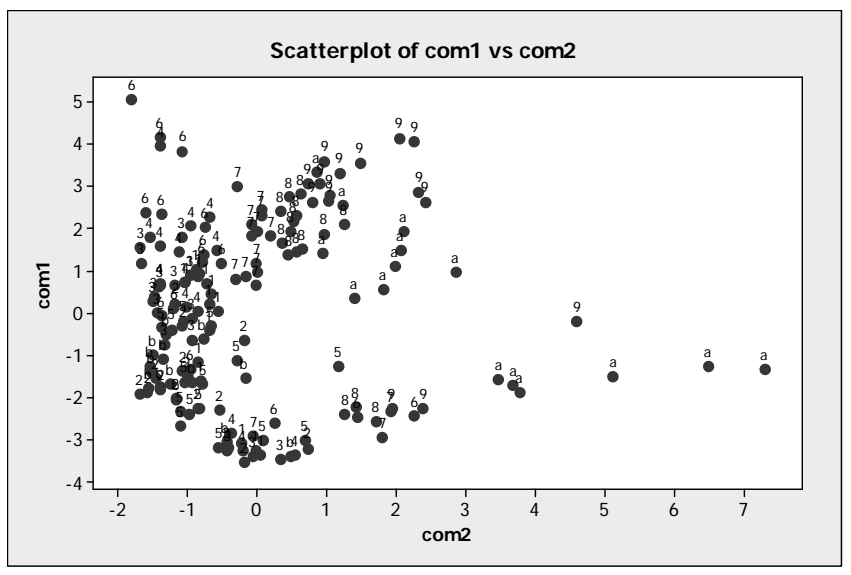

Figure 15: Analysis of the component 1 and component 2 associated to sampling months in the San Pedro River, where 1=October; 2=November; $3=$ December; 4=January; 5=February; 6=March; 7=April; 8=May; 9=June; a=July; $\mathrm{b}=$ August.

With respect to the evaluation of microorganisms in water of the San Pedro River, it was found that fecal coliform counts were the higher during July (11,000 cfu/100 ml) and August samples (1,868 cfu/100 ml) in location LJ. The number of fecal coliforms increased downstream and they exceeded the Mexican Norm values of $1,000 \mathrm{cfu}$ in $100 \mathrm{ml}$. With respect to total coliform counts, they were similar to the trend of fecal coliform; hence, highest values were obtained in July (43,000 cfu) and August samples (4,880 cfu) in location LJ.

\section{Conclusions}

The lower San Pedro River shows a significant degree of contamination in its water. This level of contamination is not permanent in all locations and might be associated with season of the year, drought events and due to anthropogenic activities. The high As concentration measured in this study raises a red flag to the health of communities settled along the San Pedro River.

\section{References}

1. Bozkurtoglu, E.; Vardar, M.; Suner, F.; Zambak, C. A new numerical approach to weathering and alteration in rock using a pilot area in the Tuzla geothermal area, Turkey. Engineering Geology, 2006, 87(1-2): 33-47.

2. White, A. F.; Marjorie, S. S.; Davison, V. V.; Alex, E. B.; Stonestrom, D. A.; Harden, J. W.: Chemical weathering rates of a soil chronosequence on granitic alluvium: III. Hydrochemical evolution and contemporary solute fluxes and rates. Geochimica et Cosmochimica Acta, 2005, 69(8):1975-1996

3. Donahue, R. L.; Miller, R. W.; Shickluna, J. C.: Soils, An introduction to soil and plant growth. Prentice may, Inc. Englewood Cliffs, New Jersey, 1983. Fifth Edition

4. Moreno, T.; Querol, X.; Castillo, S.; Alastuey, A.; Cuevas, E.; Herrmann, L.; Mounkaila, M.; Elvira, J.; Bibbons, W. Geochemical variations in Aeolian mineral particles from the Sahara-Sahel Dust Corridor. Chemosphere, 2006, 65(2): 261-270.

5. Rubio, A. H.; Saucedo, T. R.; Bautista, M. R.; Wood, K.; Holguin, C.; Jimenez, J. Are crop and range lands being contaminated with cadmium and lead in sediments tranposrted by wind from an adjacent contaminated shallow lake? Geoenvironment and Landscape Evolution. Editors: J.F. Martin-Duque, C.A. Brebbia, D.E. Emmanouloudis, U. Mander. WITPRESS, 2006, 135-141.

6. Das, A.; Krishnaswami, S.: Elemental geochemistry of river sediments from the Deccan Traps, India: Implications to sources of elements and their mobility during basalt-water interaction. Chemical Geology, 2007, 242 (1-2): 232-254.

7. Espino, M.A.; Rubio, A-H.; Navarro, C.J. 2007. Nitrate Pollution in the Delicias-Meoqui Aquifer of Chihuahua, Mexico. Environmental Health Risk Conference 2007. Republic of Malta June 27-29. Witpress, 2007; 189-196.

8. Rubio, A. H.; Wood, K.; Alanis, H. E.: Water pollution in the Rio Conchos of Northern Mexico. Develpment and application of computer techniques to Environmental Studies X. Editors; G. Latini, G. Passerini, C.A. Brebbia. WITPRESS, 2004, 167-176.

9. Rubio, A. H.; Saucedo, T. R.; Lara, C.R.; Wood, K.; Jiménez, J.: Water quality in the Laguna de Bustillos of Chihuahua, México. Water Resources Management III. Editors: M. De Conceicao Cunha, C.A. Brebbia. WITPRESS, 2005. 155-160.

10. Gutiérrez, M.; Borrego, P. Water quality assessment of the rio Conchos, Chihuahua, mexico. Environmental International, 1999, 25(5):573-583

11. Holguín, C.; Rubio, H.; Olave, M. E.; Saucedo, T. R.; Gutierrez, M.; Bautista, M. R.: Calidad del agua del río Conchos en la región de Ojinaga, Chihuahua: Parámetros fisicoquímicos, metales y metaloides. Universidad y Ciência, 2006, 22 (1):51-63

12. Gutierrez-Espinoza, R.; Rubio, A. H.; Quintana, R. M.; Ortega, J. A.; Pinedo, C.: Arsenic concentration in the San Pedro River in Delicias, Chihuahua, México. International Health Risk Conference 2007. Republic of Malta June 27-29. Witpress, 2007; 181-188

13. Norma Mexicana NMX-AA-007-SCFI-2000. Análisis de agua. Determinación de la temperatura en agua Naturales, Residuales y Residuales Tratadas. Método de prueba. Diario Oficial de la Federación del 23 de julio de 1980.

14. Norma Mexicana NMX-AA-093-SCFI-2000. Análisis de agua. Determinación de la conductividad 
electrolítica . Método de prueba. Secretaría de Comercio y Fomento Industrial CDU.631.879. 27 p.

15. Norma Mexicana NMX-AA-008-SCFI-2000. Análisis de agua. Determinación de $\mathrm{pH}$ - Método de prueba. Diario Oficial de la Federación del 25 de marzo de 1980.

16. APHA. American Public Health Association. Métodos normalizados para el análisis de aguas potables y residuales. Madrid, 1992, $1294 \mathrm{p}$.

17. Norma Mexicana NMX-AA-115-SCFI-2001. Análisis de agua. Criterios Generales para el Control de la Calidad de Resultados Analíticos. Secretaría de Economía, 37 p.

18. Norma Mexicana NMX-AA-051-SCFI-1981. Determinación de metales, método espectrofotométrico de Absorción Atómica, Diario Oficial de la Federación del 22 de febrero de 1982.

19. WHO. World Health Organization. $\mathrm{pH}$ in drinkingwater. Background document for preparation of WHO guidelines for drinking-water quality. Genova, World Health Organization 2003 (WHO/SDE/WSH/03.04/12)

20. Robinson, L; Links, T.; Smith, A.; Smith, M.; Guinan, M.; Todd, R.; Brown, L.; Dudding, B. Acute Lymphoblastic (Lymphocytic) Leukemia-Review and Recommendations of the expert panel Nevada State Health Division. 2001.

21. Steinmaus, C.; Lu, M.; Todd, R. L.; Smith, A. H.: Probability estimates for the unique childhood leukemia cluster in Fallon, Nevada, and risks near other U.S. military Aviation facilities. Environmental Health Perspectives 2004, 112(6): 766-771.

22. Chen, C. J.; Kuo, T. L.; Wu, M. M.: Arsenic and cancer. Lancet, 1988, I: 414-415

23. IARC. International Agency for Research on Cancer. Some drinking-water disinfectants and contaminants including arsenic. IARC Monograr Eval Carcinog Risks Hum 84, 2004.
24. Hopenhayn-Rich, C.; Biggs, C.; Smith, M.C. Lung and kidney cancer mortality associated with arsenic in drinking water in Cordoba, Argentina. Int. J. Epidemiol, 1998, 27:561-569.

25. NRC. National Research Council. Arsenic in drinking water; 2001 update. Washington, D.C. National Academy Press. 2001.

26. Muller-Quernheim, J.: Chronic Beryllium disease. Orphanet. 2005. http://www.orpha.net/data/ patho/GB luk-CBD.pdf

27. Shoental, R. Chromium carinogenesis, formation of epoxyaldehydes and tanning. Br, J. Cancer, 1975, 32: 403-404

28. Gómez, S.; Altamirano, M.; Villalobos, R. SisterChromatid exchanges induced by some chromium compounds in human lymphocytes in vitro. Mutation Res, 1981, 90:425-431.

29. Monarrez, E. J.; Martinez, H.; Greiner, J. Iron deficiency anemia in Tarahumara women of reproductive-age in Northern Mexico. Salud Publica de Mexico, 2001, 43:392-401.

30. Bradford, G. L.: Lithium survey of California`s water resources. Soil Science, 1963, 96:77-81

31. Feder, G. L. Geochemical survey of Missouri. Open file report. United States Geological Survey. 1972.

32. Emery, R. D.; Klofer, C.; Skalski, J. R. The incipient toxicity of lithium to freshwater organisms representing a salmonid habitat. PNC-3640, UC-II. Pacific Northwest Laboratory; Richland, WA, USA, 1981. 364 p.

33. Rubio, A. H.; Quintana, R.; Word, K.; Saucedo, T. R.; Bautista, M. R.: Vanadium and Lithium contamination in freshwaters of the Conchos river in Chihuahua, Mexico. Environmental Health Risk Conference 2007. Republic of Malta, June 27-29. Witpress, 2007; 171188. 